\title{
CHARACTERIZATION OF TRANSVERSE CYLINDRICAL CAVITIES IN WOODEN BLOCKS OF THE SPECIES Cedrela odorata USING NON- DESTRUCTIVE ULTRASOUND TESTS
}

\author{
Luis Yoza Yoza ${ }^{1}$, Erik Baradit Allende ${ }^{2}$, Oscar Tang Cruz ${ }^{3}$, Jorge Luis Monteiro de Matos ${ }^{4}$, Márcio Pereira da \\ Rocha $^{4}$, Ivan Venson ${ }^{4}$ \\ ${ }^{1,3}$ Universidad Nacional Agraria La Molina, Departamento de Física y Meteorología \\ lyoza@lamolina.edu.pe; otang@lamolina.edu.pe Lima, Perú \\ ${ }^{2}$ Universidad de Bio Bio, Concepcion Chile Facultad de Ciencias ebaradit@ubiobio.cl; \\ ${ }^{4}$ Universidade Federal do Paraná, Departamento Engenharia e Tecnologia Florestal, Curitiba, Paraná, Brasil - \\ jmatos.ufpr@gmail.com; mprocha01@gmail.com; venson.ivan@gmail.com \\ Received for publication: 02/05/2020 - Accepted for publication: 30/10/2020
}

\begin{abstract}
Resumo
Caracterização de cavidades cilíndricos transversais em blocos de madeira da espécie Cedrela odorata utilizando testes não destrutivos de ultrassom. Caracterizar as cavidades cilíndricas transversais em blocos de madeira de Cedrela odorata usando as técnicas não destrutivas (TND) de ultrassom foi o objetivo principal do presente trabalho. Foram medidas as dispersões de velocidade de propagação de ondas acústicas (AWV) e considerando a estrutura anisotrópica da madeira, se utilizou o modelo de Hankinson para sua modelagem com gráficos em 2D. Os resultados mostraram uma forte dispersão na direção frontal dependente do diâmetro das cavidades, além de boas relações lineares entre elas para o eixo da cavidade. Os resultados permitiram mostrar a potencialidade do uso de técnicas TND de ultrassom em avaliações de elementos estruturais deteriorados como os monumentos históricos.

Palavras chaves: Técnicas não destrutivas, ultrassom, deterioração da madeira.
\end{abstract}

\section{Abstract}

The main objective of the present work was to characterize the transverse cylindrical cavities of Cedrela odorata wood blocks using the non-destructive ultrasound techniques (NDT). The dispersions of acoustic wave propagation velocity (AWV) were measured and, considering the anisotropic structure of the wood, the Hankinson model was used for modeling with 2D graphics. The results showed strong dispersion in the frontal direction depending on the diameter of the cavities, in addition to good linear relationships between them for the cavity axis. Therefore, the results support the use of NDT ultrasound techniques to assess deteriorated structural elements such as historical monuments.

Keywords: Non-destructive techniques, ultrasound, wood deterioration.

\section{INTRODUCTION}

This study was motivated by the need to find techniques that can be used to evaluate the structural elements of wood from 300 years old historical monuments in Peru. Due to their old age, these historical monuments have undergone both abiotic and biotic deterioration processes over time. It is essential that techniques used in evaluations cause minimal damage to buildings, making non-destructive techniques (NDT) very suitable for this purpose, as indicated by Vizcarra (2018). This author used such techniques to restore the El Comercio Hotel in Lima and the Ica City Cathedral, thus demonstrating the importance of using NDT for this purpose.

The objective of this study was to use wooden blocks of the species Cedrela odorata to study the behavior of ultrasound wave propagation in wood cavities, using the Hankinson model and measuring propagation times with the FAKOPP Micro Timer equipment.

Other similar works, such as that by Armstrong, Patterson and Sneckenberger (1991), are noteworthy because they compared the Hankinson Model with various types of regressions on panels of the species birch, black cherry and red oak, among others, and found that the Hankinson model provides the best approximation with lowest absolute mean error (AAE).

Sotomayor and Villaseñor (2016) used two species to prepare angularly oriented specimens in the longitudinal to tangential direction and obtained the propagation velocities and elastic modules of each. They found that the velocities varied more for Thuja plicata than for Acer saccharum, which is confirmed by the determination coefficients found (0.978 and 0.999 , respectively). Furthermore, they found no significant differences when comparing the elastic modules of the oriented specimens and those calculated using the Hankinson equation.

Huandong et al., (2014) used a Rinntech tomograph for 7 x 34 x $76 \mathrm{~cm}$ Populus usuriensis wood blocks with rectangular cavities and noted that the propagation time curves of the acoustic wave (AWT) were symmetrical to the cavity axis and associated with an increase in the time elapsed. 
Acuña, Diez y Casado (2006) related the ultrasound propagation velocities at $30 \mathrm{kHz}$ to different angles in relation to the longitudinal direction in the species Pinus sylvestris, Pinus pinaster, Pinus radiata, Fagus selvática and Chlorophora excelsa. The authors observed a similar velocity reduction behavior by applying the Hankinson model as a second-order polynomial model, which was easier to apply. In addition, they found that the influence of the longitudinal dimensions of the specimens was not significant for small samples.

Espinosa et al. (2019) measured the propagation time of $60 \mathrm{kHz}$ ultrasound waves generated on the outer edge of a Fagus sylvatica disc, with central perforations made at $2.9 \mathrm{~cm}, 5.1 \mathrm{~cm}$ and $7.6 \mathrm{~cm}$ in diameter. They observed that the velocities decrease significantly with the diameter of the cavities in the zone between the radial direction until an angle of $40^{\circ}$, and also that the medulla acts as a new source of waves.

On the other hand, Hearing, Keunecke and Niemz. (2012) found that by increasing the moisture content from $8.7 \%$ to $16.2 \%$ in beech wood, there could be a decrease in Young's module by $21.1 \%, 8.3 \%$ and $25.6 \%$ in the radial, longitudinal and tangential directions. This result demonstrates the importance of considering this factor in studies that use samples with low moisture contents.

Therefore, associated non-destructive techniques, such as ultrasound and resistographs, have been used and have provided good results for evaluations of historical monuments, e.g., the Guanyin Temple, Shanxi Province in China (WANG et al., 2019).

\section{MATERIAL AND METHODS}

\section{Materials and equipment}

The study was divided into two parts, using wooden blocks with perforations transversal to the longitudinal/radial (RL) and longitudinal/tangential (TL) planes. Due to the restrictions on the use of cedar wood, we found woods with dimensions closest to the beams of historical monuments and that were appropriate for nondestructive samples. Thus, we used three Cedrela odorata wood blocks with the following dimensions:

Block 1: $\mathrm{L}=39.4 \mathrm{~cm}, \mathrm{R}=15.5 \mathrm{~cm}$ and $\mathrm{T}=7.0 \mathrm{~cm}$, radial longitudinal plane $(\mathrm{RL})$

Block 2: $\mathrm{L}=40.0 \mathrm{~cm}, \mathrm{R}=20.0 \mathrm{~cm}$ and $\mathrm{T}=7.8 \mathrm{~cm}$, radial longitudinal plane $(\mathrm{RL})$

Block 3: $\mathrm{L}=39.6 \mathrm{~cm}, \mathrm{~T}=19.6 \mathrm{~cm}$ and $\mathrm{R}=7.6 \mathrm{~cm}$, tangential longitudinal plane $(\mathrm{TL})$.

The samples or blocks were placed in a climatic chamber at $20^{\circ} \mathrm{C}$ and $60 \%$ relative humidity, with an average moisture content of $12 \%$.

For the tests, a $23 \mathrm{kHz}$ FAKOPP Micro Timer ultrasound equipment with $\pm 0.5 \mu$ s accuracy and type P wave was used. To determine the moisture content of the blocks, a Sanko TH-2C $\pm 0.2 \%$ moisture meter was used, along with a computer and other small equipment.

\section{Methods}

Herein, the ultrasound technique was used to characterize the anisotropic properties of the three wooden blocks, with five transversal cavities perforated in each one. Cylindrical cavities with diameters of $1.9 \mathrm{~cm}, 2.5 \mathrm{~cm}$, $3.2 \mathrm{~cm}, 5.4 \mathrm{~cm}$ and $6.4 \mathrm{~cm}$ were drilled, with largest cavity diameter serving to adjust the model, as shown in the results.

The ratios of ultrasound wavelengths used by the equipment versus the transverse size of blocks 1,2 and 3 were 2.1, 3.4 and 3.3 times, respectively, considering that a good ratio to avoid larger dispersions is 3 . However, for block 1, a smaller factor was used to resemble a real beam and had a slightly influential result.

When applying the Hankinson Method to wood, as anisotropic material, the acoustic propagation velocities (AWV) depend on the direction of wave propagation. For radial longitudinal (RL) and tangential longitudinal (TL) planes, they vary similarly according to the angle $\theta$ that forms the wave propagation with the longitudinal direction, taking away values from the velocity in the L direction and decreasing until reaching the value in the $\mathrm{R}$ or $\mathrm{T}$ direction. For a source located at the center point of the plane, this variation is governed by the Hankinson equation (USDA, 1999), which is:

$$
V_{\theta}=\frac{V_{L} V_{R}}{V_{L} \operatorname{sen}^{n}(\theta)+V_{R} \cos ^{n}(\theta)}
$$

Where: $V_{L}, V_{R} y V_{\theta}$ in $\mathrm{m} / \mathrm{s}$, are the AWV in the longitudinal and radial directions and for angle $\theta$; with " $\mathrm{n}$ " being an adjustment parameter to determine the value, which ranges from 1.6 to 1.9. Estimating an error of $7.9 \%$ by using the differencial of the equation and the angular errors and VL and $V_{R}$ velocities (Table 1). Furthermore, indicating that the procedures should be performed in a well-controlled environment and in the shortest amount of time, so the moisture content of the samples do not change significantly.

Herein, the following methodology was established: 
a) Evaluation of the clean block or block without cavities. First, a $2 \times 2 \mathrm{~cm}$ square grid was drawn on the side being studied, placing the point " 0.0 " in the middle of the upper edge (Figure 1). Then, the longitudinal and transverse reference velocities of each block were determined, according to the model equation, by placing the sensors on the lateral sides of the block with a total of 27 measurements on three levels.

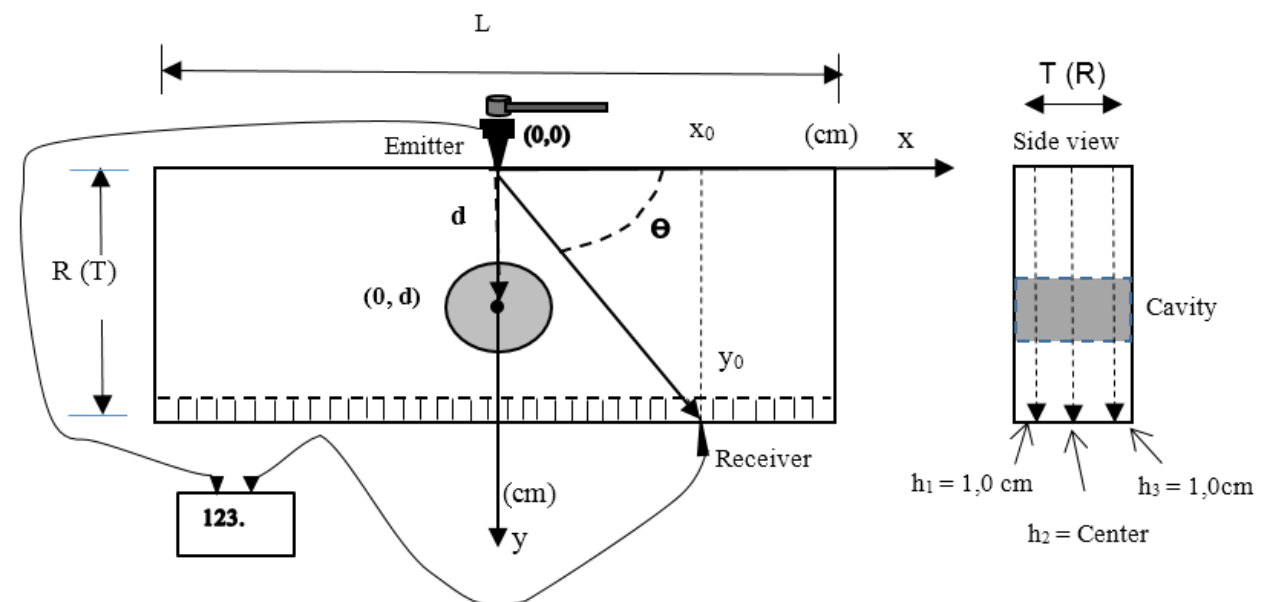

(a)

(b)

Figure 1. Arrangement for measurements. Block dimensions: L- length, R(T)- width, and T(R) -height of the block in $\mathrm{cm}$; (a)- front view of block position of the emitter and receiver with respect to angle $\theta$; cavities with diameters of $1.9 ; 2.54 ; 3.2 ; 5.4$ and $6.4 \mathrm{~cm}$, whose centers are at a distance of $\mathrm{d}=8.0 ; 13.5$ and $15.5 \mathrm{~cm}$ from the emitter for blocks 1, 2 and 3, respectively. (b)- side view (height) of the block, with measurement surfaces at $h_{1}=h_{3}=1.0 \mathrm{~cm}$ from the sides and $h_{2}$ in the center.

Figura 1. Disposição para as medições. Dimensões do bloco: L - comprimento, R (T) - largura e T (R) - altura do bloco em cm; (a) - vista frontal do bloco, posição do emissor e receptor em relação ao ângulo $\theta$; cavidades com diâmetros de 1,$9 ; 2,5 ; 3,2 ; 5,4$ e $6,4 \mathrm{~cm}$, cujos centros se encontram à distância d = 8,0; 13,5 e 15,5 cm do emissor, para os blocos 1, 2 y 3, respectivamente; (b) - vista lateral (altura) do bloco, com as superfícies de medição $\mathrm{h}_{1}=\mathrm{h}_{3}=1,0 \mathrm{~cm}$ das faces e $\mathrm{h}_{2}$ no centro.

b) With the blocks cleaned, the propagation velocities were determined, if the emitting sensor was set at the " 0.0 ", measuring the respective propagation time values to the receiving sensor, located at the bottom vertex of each square on the lower edge, using the angle " $\theta$ " (Figure 1). Measurements were repeated at three levels in relation to the side being studied, $\mathrm{h}_{1}=1.0 \mathrm{~cm}, \mathrm{~h}_{2}$ in the center and $\mathrm{h}_{3}=1.0 \mathrm{~cm}$ from the bottom, totaling 306 measurements per block. In parallel, the velocities were calculated for the same angles, using the Hankinson equation with an initial value of $n=1.7$, which was adjusted later.

c) Evaluation of blocks with cavities. In this case, the cavities perpendicular to the side of the block being studied were drilled, starting from the smaller diameter to the largest diameter. After drilling, the respective measurements were collected (Figures 1 and 2) by locating the centers of the cavities at distances (d) of 8.0, 13.5 and $15.5 \mathrm{~cm}$ from the emitter, for blocks 1, 2 and 3, respectively. For the cavities, measurements of propagation velocities were performed similarly to those without cavities, with a total of 306 measurements at three levels.

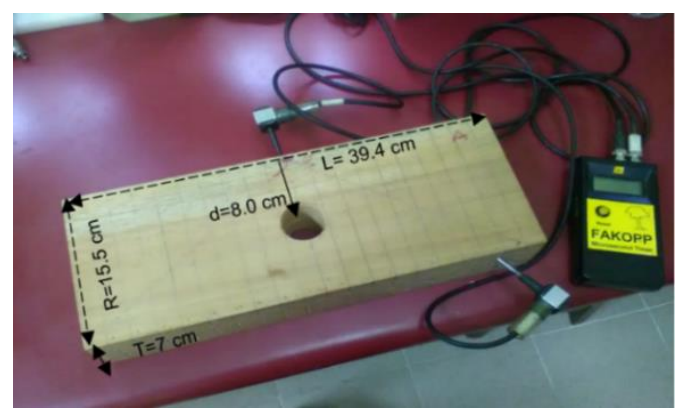

Figure 2. Block 1 with a $2.5 \mathrm{~cm}$ diameter cavity, layout of the $23 \mathrm{kHz}$ Micro Timer ultrasound equipment.

Figura 2. Bloco 1 com cavidade de 2,5 cm de diâmetro, disposição do equipamento de ultrassom Micro Timer de $23 \mathrm{kHz}$. 


\section{RESULTS}

\section{Ultrasound wave transfer tests with central emitter}

Using procedure "a", the reference velocities $\mathrm{V}_{\mathrm{L}}$ and $\mathrm{V}_{\mathrm{R}}$ or $\mathrm{V}_{\mathrm{T}}$ were determined, as described in Table 1, under laboratory conditions. Using procedure " $\mathrm{b}$ ", the equivalent velocities were measured for each angle " $\theta$ ", selecting and creating the respective database. Then, with the appropriate Hankinson equation with the reference velocities and the same angles " $\theta$ ", the database for the blocks was formed, which allowed for comparisons between both databases and provided the "n" parameter of best fit, as shown in Figure 3, for block 1.

From these results, it is noted that the model used is very close to the experimental results after minimizing the differences between them, with average values of $8.7 \%, 5.5 \%$ and $6.6 \%$, with " $n$ " values of $1.66,1.79$ and 1.83 for blocks 1,2 and 3, respectively, which agrees with the average of $7.9 \%$ indicated for the equation. These results were compared with the other measurement levels, with similar results.

Table 1. Velocities in the longitudinal main axes $\left(\mathrm{V}_{\mathrm{L}}\right)$ and transversal $\left(\mathrm{V}_{\mathrm{R}}\right)$ and $\left(\mathrm{V}_{\mathrm{T}}\right)$, Hankinson's equation. Tabela 1. Velocidades nos eixos principais longitudinal $\left(V_{L}\right)$ e transversal $\left(V_{R}\right)$ e $\left(V_{T}\right)$, equação de Hankinson.

\begin{tabular}{|c|c|c|c|c|}
\hline & $\begin{array}{l}\text { Longitudinal } \\
\text { Velocity } \\
\left(\mathrm{V}_{\mathrm{L}}\right) \mathrm{m} / \mathrm{s}\end{array}$ & $\begin{array}{l}\text { Transversal } \\
\text { Velocity } \\
\left(\mathrm{V}_{\mathrm{R}}\right) \mathrm{m} / \mathrm{s}\end{array}$ & $\begin{array}{l}\text { Transversal } \\
\text { Velocity } \\
\left(\mathrm{V}_{\mathrm{T}}\right) \mathrm{m} / \mathrm{s}\end{array}$ & $\begin{array}{c}\text { Parameter } \\
\mathrm{n}\end{array}$ \\
\hline 1 & $\begin{array}{c}4413.2 \pm 127.3 \\
\text { CV }(2.9 \%)\end{array}$ & $\begin{array}{c}1735.8 \pm \\
68.9 \\
\text { CV }(4 \%)\end{array}$ & & $\begin{array}{l}1.66 \\
8.7 \%\end{array}$ \\
\hline 2 & $\begin{array}{c}4456.7 \pm 132.9 \\
\text { CV }(2.98 \%)\end{array}$ & $\begin{array}{c}1345.1 \pm \\
183.0 \\
\operatorname{CV}(15.3 \%)\end{array}$ & & $\begin{array}{c}1.79 \\
5.5 \%\end{array}$ \\
\hline 3 & $\begin{array}{c}4053.2 \pm 227.8 \\
\text { CV }(5.6 \%)\end{array}$ & & $\begin{array}{c}1367.7 \pm \\
148.1 \\
\text { CV }(12.2 \%)\end{array}$ & $\begin{array}{c}1.83 \\
6.6 \%\end{array}$ \\
\hline
\end{tabular}

Where: \pm - standard deviation, CV - coefficient of variation

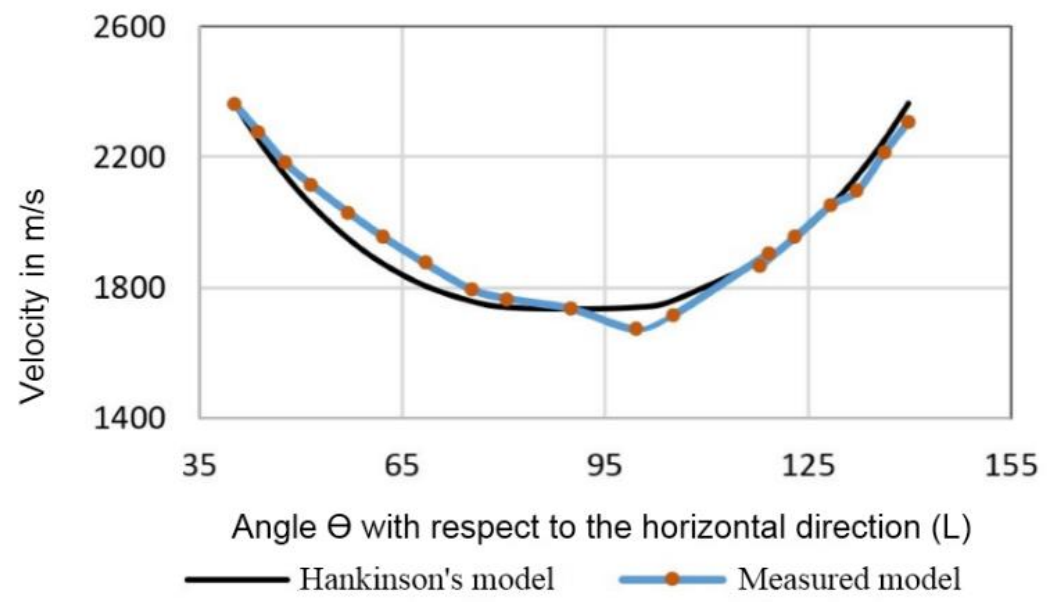

Figure 3. Hankinson's model and measured values from block 1 of Cedrela odorata without cavity, $\mathrm{n}=1,66$. Figura 3. Modelo de Hankinson e valores medidos do bloque 1 de Cedrela odorata sem cavidade, $\mathrm{n}=1,66$.

For procedure "c", the models were first represented graphically (in black) and then the velocities of cavities with different diameters were added. The results clearly show the influence of cavity size, with axes located in the $90^{\circ}$ direction. There is also a marked difference between propagation in the RL plane (blocks 1 and 2) in Figures 4 and 5 compared to the TL plane (block 3), represented in Figure 6, with smaller dispersion in the latter around $90^{\circ}$. Such results are similar to those found in the other two levels studied. 


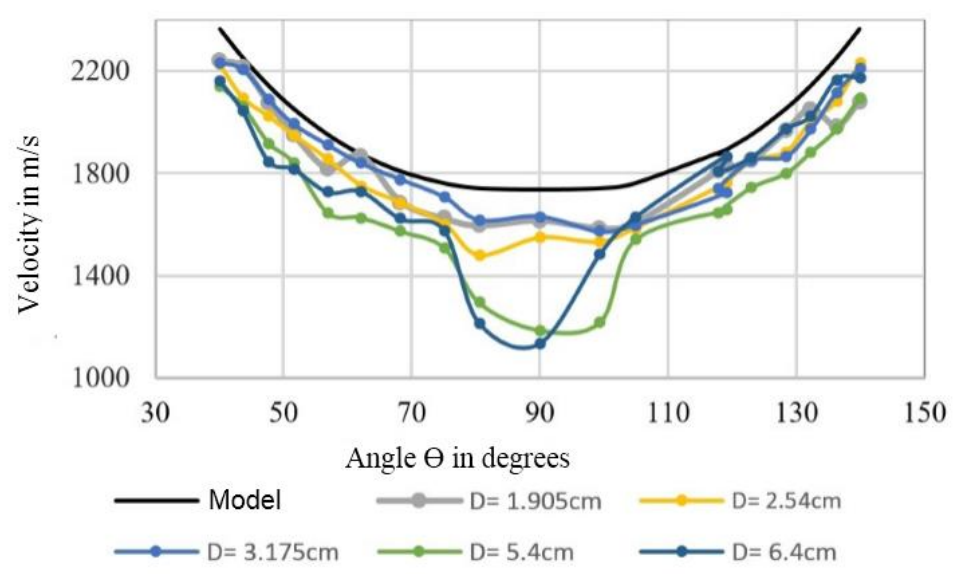

Figure 4. Block 1, velocities for angle $\theta$ values measured at $1 \mathrm{~cm}$ from the surface $(\mathrm{RL}), \mathrm{n}=1.66$.

Figura 4. Bloco 1, velocidades para valores do ángulo $\theta$ medidas a $1 \mathrm{~cm}$ da superfície $(\mathrm{LR}), \mathrm{n}=1,66$.

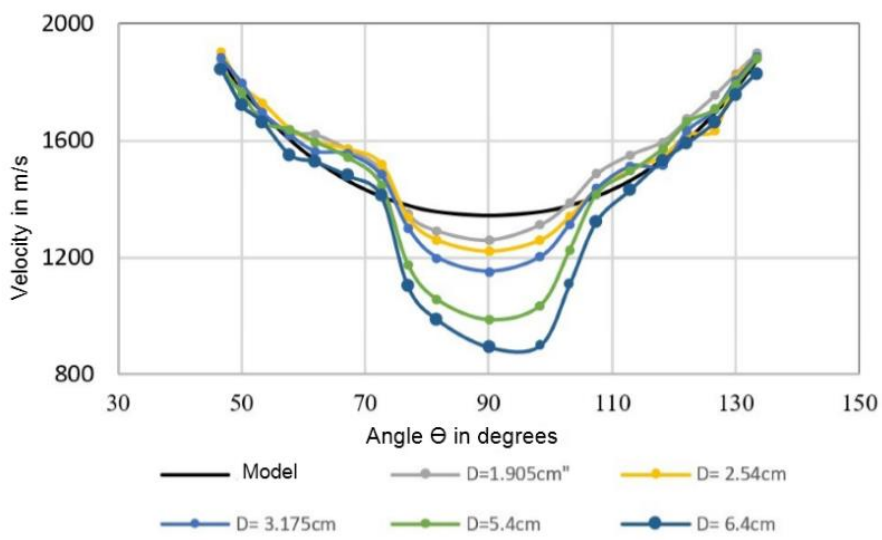

Figura 5. Bloco 2, velocidades para o ângulo $\theta$ medidas a $1 \mathrm{~cm}$ da superficie $(\mathrm{LR}), \mathrm{n}=1,79$.

Figure 5. Block 2, velocities for angle $\theta$ measured at $1 \mathrm{~cm}$ from the surface $(\mathrm{RL}), \mathrm{n}=1.79$.

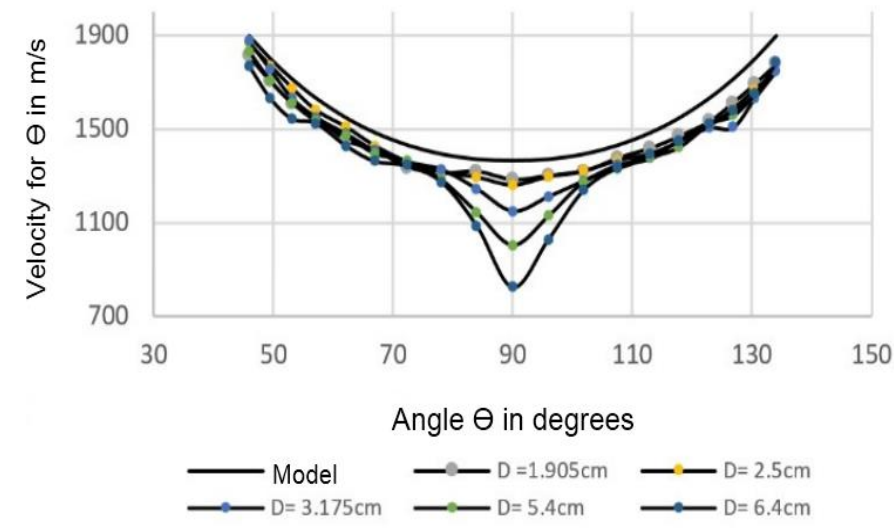

Figure 6. Block 3, velocities for angle $\theta$ measured at $1 \mathrm{~cm}$ from the surface (TL), $\mathrm{n}=1.83$.

Figura 6. Bloco 3, velocidades para o ângulo $\theta$ medidas a $1 \mathrm{~cm}$ da superfície (LT), $\mathrm{n}=1,83$.

From the data of the $90^{\circ}$ direction between the velocities and cavity diameters, an inverse relationship was obtained, with high determination coefficients of $0.898,0.982$ and 0.938 for blocks 1,2 and 3 , respectively. This indicates that there is marked dispersion of ultrasound velocities in relation to cavity diameters, given by the relationships to a moisture content of $12 \%$ : 
$\mathrm{V} 1=-101.54 \times \mathrm{d}_{1}+1804.5 ; \mathrm{R}^{2}=0.897$

$\mathrm{V} 2=-72.73 \times \mathrm{d}_{2}+1378.3 ; \mathrm{R}^{2}=0.982$

$\mathrm{v} 3=-83.202 \times \mathrm{d}_{3}+1426.7 ; \mathrm{R}^{2}=0.939$

Where: $\mathrm{v}_{1}, \mathrm{v}_{2}$, and $\mathrm{v}_{3}$ are the velocities in $\mathrm{m} / \mathrm{s}$ and $\mathrm{d}_{1}, \mathrm{~d}_{2}$ and $\mathrm{d}_{3}$ are the diameters in cm for blocks 1,2 and 3 , respectively.

The graphs of the blocks with $6.4 \mathrm{~cm}$ cavities show marked asymmetry in relation to the $90^{\circ}$ axis, in which the velocities \pm 5 degrees before and after were compared, with the following results: $23.8 \%$ (block 1), $9.9 \%$ (block 2) and $6.3 \%$ (block 3 ). For the $5.4 \mathrm{~cm}$ cavity, the results were $6.3 \%$ (block 1), 1.9\% (block 2) and $1.4 \%$ (block 3 ). These results indicate that the higher asymmetry of the $6.4 \mathrm{~cm}$ cavity marks the limit of the model used.

In general, the precision of the work is fixed by an average error of $6.7 \%$ in the adjustment of Hankinson's model, with the velocities of the clean blocks for the moisture content of $12 \%$. On the other hand, we found the maximum diameter of asymmetry accepted for the cavities, indicated above, and the determination coefficients for determining the correlations obtained in the equations $\mathrm{V}_{1}, \mathrm{~V}_{2}$ and $\mathrm{V}_{3}$. In addition, an ANOVA was performed within the angular variation of the cavities between $90^{\circ} \pm 15^{\circ}$ with a single value, considering the model Velocity $=\beta_{0}+\beta_{1}$ diameter $+\beta_{2}$ block $+\beta_{3}$ (diameter*block). Previously, compliance with the assumptions of normality (W Shapiro Wilk $=0.97$; p-value $=0.05$ ) and homoscedasticity (Chi-square $=2.98$; p-value $=0.05)$ was corroborated. The results indicate that both the blocks $\left(\mathrm{F}=108.7\right.$; $\mathrm{p}$-value $\left.<2 \times 10^{-6}\right)$ and diameter $(\mathrm{F}=129.8 ; \mathrm{p}$ value $<2 \times 10^{-6}$ ) significantly affect the variable velocity, with $95 \%$ confidence level. Even so, there is no interaction effect $(\mathrm{F}=0.72$; $\mathrm{p}$-value $=0.48)$. Thus, the effect of diameter on velocity does not vary according to the block studied, nor did the wavelength and size of the block influence it. Figure 7 clearly shows the inverse relationship in block 1 .

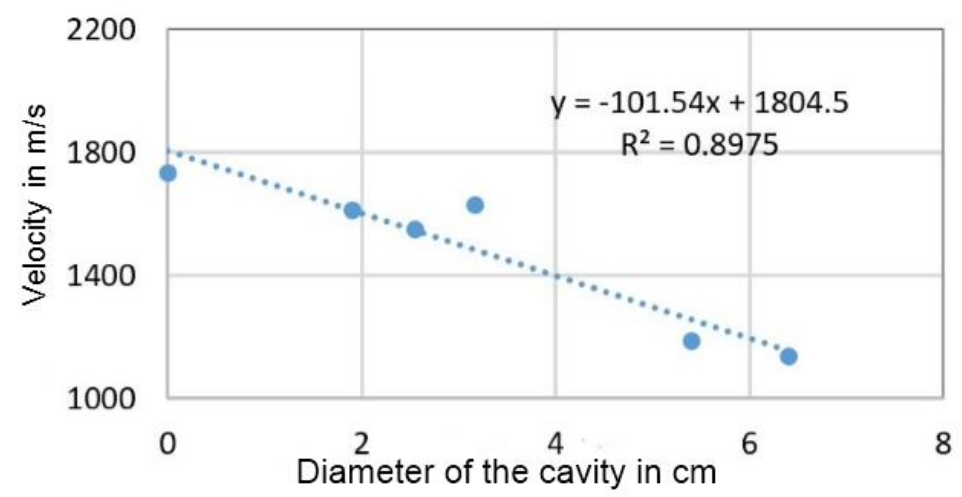

Figure 7. Block 1, Relationship between velocity and cavity diameter for $\theta=90^{\circ}$.

Figura 7. Bloco 1, Relação entre velocidade e diâmetros das cavidades para $\theta=90^{\circ}$.

\section{DISCUSSION}

According to the results, Hankinson's model was the most suitable for the present study since it adapted to different block types and dimensions, only varying in the "n" parameter, as shown in Figures 4, 5 and 6 , indicating that the model is very close to the experimental data with mean adjustments of $8.7 \%, 5.5 \%$ and $6.6 \%$, respectively. Furthermore, Acuña, Diez and Casado (2006), who studied the anisotropic behavior of this species, obtained a high coefficient of determination in the order of 0.9, which corroborates with Armstrong et al. (1991).

On the other hand, it is important to consider what Hearing, Keunecke and Niemz. (2012) observed regarding the influence of the moisture content of the wood in the measurements of the Young module, having to control the humidity conditions of the sampled, laboratory environment, and to a lesser extent in situ tree measurements very well. It is also important to observe the behavior of wave dispersion in the RL plane - blocks 1 and 2 (Figures 4 and 5) were higher than in TL plane- block 3 (Figure 6). This could be due to the presence of growth rings and rays in the RL plane, which influence dispersion, while in the TL plane the material is more homogeneous and wave propagation in the wood layers are more uniform. Finally, it is necessary to establish measurement protocols according to the species, cavity geometry, and moisture content of the wood for application in the laboratory and in situ. 


\section{CONCLUSIONS}

- There is a strong correlation between the velocities measured for the different angles in each block and the values of the Hankinson model.

- For the $90^{\circ}$ angle, there was a strong linear correlation between the cavity diameters and velocities for this angle under controlled moisture content and laboratory environment conditions.

- The use of NDT with ultrasound is recommended for studies of old/ancient structural elements due to the good results obtained.

- Dispersions in RL and TL planes with longitudinal cavities perforated in the blocks should be compared.

\section{REFERENCES}

ACUÑA, L.; DIEZ, M.; CASADO, M. Los ultrasonidos y la calidad de las maderas estructurales, Aplicación a Pinus pinaster Ait. Boletin de CIDEU 2-7-26, 2006.

ARMSTRONG, J.; PATTERSON, D.; SNECKENBERGER, J. Comparison of three equations for predicting stress wave velocity as a function of grain angle. Wood and Fiber Science 2, 1991.

BARROS, C. Behavior of ultrasonic waves in wood with presence of holes. Cerne Lavras 18(3) 507-514, 2012.

ESPINOSA, L; PRIETO, F.; BRANCHERIAU, L.; LASAYGUES P.; Effect of Wood anisotropy in ultrasonic wave propagation: Array tracing approach. Ultrasonic 91, 242-251, 2019.

HEARING, S.; KEUNECKE, D.; NIEMZ, P. Moisture- dependent orthotropic elasticy of beech wood, Wood Sci. Technol, 46: 927-938, 2012.

HUADONG, X.; GUOQI, X.; WANGE. L.; LEI. Y. Propagation behavior of acoustic wave in wood, Journal of Forestry Research., Volume 25, Issue 3, pp 671-676, 2014.

SHARMA, SK.; SHUKLA, SR. Evaluación de defectos en madera mediante ultrasonido no destructivo. Revista de la Academia de Ciencias de la Madera 9,66-77, 2012.

SOTOMAYOR, J.; VILLASEÑOR, J. Ultrasonido y anisotropía en madera de Thuja plicata y Acer saccharum. Maderas, Cienc. tecnol. vol.18 no.3 Concepción jul. p 467 - 476, 2016.

VIZCARRA, D.; CANO, J.; YOZA, L.; ACEVEDO, M. Propuesta metodológica para la evaluación de estructuras de madera en monumentos históricos - caso Hotel El Comercio. Revista Forestal del Perú, 33 (2): 117 - 132 , ISSN 0556-6592 (Versión impresa) / ISSN 2523-1855 (Versión electrónica), 2018.

WANG, Z.; MA, D.; QIAN, W.; WANG, W.; GUO,X.; XU, Q.; HUAN, J.; GAO, Z. Detection and prediction of internal demage in the ancient timber structure based on optimal combined model, Advanced in Civil Engineering, articule ID 7108262, 18 p, 2019.

UNITED STATE DEPARTAMENT OF AGRICULTURE (USDA). Wood Handbook, Wood as an Engineering Material, General Technical Report FPL-GTR-113. Forest Serv., Forest Prod. Lab., Madison, WI,1999. 